\title{
Fruit Characteristics and Mineral Nutrient Concentrations Depending on Different Sizes of "Fuyu" Persimmon Fruits
}

\author{
Seong-Tae Choi*, Gwang-Hwan Ahn, Eun-Gyeong Kim, Ji-Young Son, Yeo-Ok Park, \\ Wan-Kyu Joung
}

Sweet Persimmon Research Institute, Gyeongsangnam-do Agricultural Research and Extension Services, Gimhae, Republic of Korea

Email: *stchoi1234@korea.kr

How to cite this paper: Choi, S.-T., Ahn, G.-H., Kim, E.-G., Son, J.-Y., Park, Y.-O. and Joung, W.-K. (2019) Fruit Characteristics and Mineral Nutrient Concentrations Depending on Different Sizes of "Fuyu" Persimmon Fruits. Agricultural Sciences, 10, 1015-1022.

https://doi.org/10.4236/as.2019.108076

Received: June 24, 2019

Accepted: August 5, 2019

Published: August 8, 2019

Copyright (๑) 2019 by author(s) and Scientific Research Publishing Inc. This work is licensed under the Creative Commons Attribution International License (CC BY 4.0).

http://creativecommons.org/licenses/by/4.0/

\begin{abstract}
This study investigated the relationships between fruit size and other fruit quality components in "Fuyu" persimmon. The flower buds were thinned to leave one or two buds per bearing shoot in mid-May. All fruits were harvested on November 12 and they were divided into six size classes by fresh weight. The length/diameter (L/D) ratio and flesh firmness significantly decreased as fruit size increased. Large fruits had a redder skin color with more seeds than small ones. There was a strong negative relationship between fruit size and the $L / D$ ratio $\left(R^{2}=0.741, p \leq 0.01\right)$ and firmness $\left(R^{2}=0.604, p \leq\right.$ $0.01)$. Skin color and number of seeds per fruit were positively related to fruit size, especially skin color where the relationship was highly positive $\left(\mathrm{R}^{2}=\right.$ $0.771, \mathrm{p} \leq 0.01$ ). There was a weak, but non-significant positive relation between fruit size and soluble solids. P, K, and Ca concentrations significantly decreased with increasing fruit size. Highly negative relationships were found between fruit size and fruit $P\left(R^{2}=0.393, p \leq 0.01\right), K\left(R^{2}=0.446, p \leq 0.01\right)$, and $\mathrm{Ca}\left(\mathrm{R}^{2}=0.417, \mathrm{p} \leq 0.01\right)$ concentrations. Fruit $\mathrm{N}$ and $\mathrm{Mg}$ concentrations were not affected by fruit size. It was concluded that fruit size is related to shape, coloration, flesh firmness, and number of seeds per fruit, affecting concentrations of some mineral nutrients in fruits.
\end{abstract}

\section{Keywords}

Fruit Quality, Fruit Weight, Maturity, Seed, Inorganic Element

\section{Introduction}

Fresh fruit from the late maturing persimmon cultivar "Fuyu" accounts for the largest portion of the total persimmon production in Korea. In general, the size 
of the fresh fruits determines the grade of the fruit, which is the most important factor affecting the price. The production of large fruits is strongly correlated with farmer profits. Therefore, most "Fuyu" growers hand-thin flower buds before flowering and some of the fruitlets after June-drop to reduce crop load so that the remaining fruits become larger at harvest. However, the production of medium-sized fruits, produced by maintaining high fruit loads, has gradually increased because producing large-sized fruits requires substantial labor inputs and medium size becomes more attractive to some consumers. In export markets, such as Southeast Asia, small- or medium-sized fruits have become better acceptable to consumers due to their long self-life with low price. "Fuyu" growers harvest the fruits over a short period of time just before heavy frosts occur in early to mid-November, and they grade the fruit mainly by their size. These fruits are then shipped to diverse markets or they are stored at low temperature. Therefore, other quality factors, such as skin color, firmness, and soluble solids, are mostly overlooked compared to fruit size.

Changes in fruit quality due to fruit size have been mainly investigated by comparing fruit-load treatments in many other studies. Large fruits from low fruit-load trees tend to have higher soluble solid concentration and coloration, but lower flesh firmness [1] [2] [3]. These characteristics are probably due to greater carbohydrate availability [4] [5]. Previous studies have shown that large apple fruits tend to mature faster than small ones with higher coloration and soluble solid concentration [3] [4]. However, the relationships between persimmon fruit size and other fruit quality components are not clear for fruits harvested at the same time, regardless of fruit load. Even on the same tree, fruit weight could be affected by several factors, including the light environment [6], different fruit loads [7], and number of seeds per fruit [8]. Under different fruit loads, fruit concentrations of mineral nutrients could vary depending on the fruit size [3] [9] [10] [11], which may also affect other fruit characteristics and storability [12].

Therefore, knowing how fruit sizes are related to other quality components is critically important to post-harvest management based on fruit size, but the mutual relationships have not been specifically elucidated for persimmon. The aim of this study was to investigate changes in fruit characteristics and their mineral nutrients when different sized fruits were harvested at the same time in mid-November.

\section{Materials and Methods}

\subsection{Plant Material}

Sixteen-year-old "Fuyu" trees (Diospyros kaki), grafted on D. kaki seedlings, were used in this experiment. The trees were spaced $6 \times 5 \mathrm{~m}$ apart and grown on flat land $\left(35^{\circ} 28^{\prime} 29^{\prime \prime} \mathrm{N}, 128^{\circ} 71^{\prime} 78^{\prime \prime} \mathrm{W}\right)$ with sandy loam soils at Gimhae, South Korea. Annual rainfall of the area ranges 1200 to $1500 \mathrm{~mm}$ and annual mean temperature $12.3^{\circ} \mathrm{C}$ to $14^{\circ} \mathrm{C}$. Conventional fertilization and irrigation recommended by RDA (2013) [13] were applied to the trees. For this experiment, 
Three similar sized trees were selected and their flower buds were thinned in mid-May to leave one bud in a below $20-\mathrm{cm}$ long shoot and two buds in an over $20-\mathrm{cm}$ long shoot. Unmarketable fruits were removed from early July to harvest after physiological fruit drop had finished. Since physiological fruit drop differed depending on the position of the fruit in the tree canopy, the leaf-to-fruit ratio per 1-year-old branch varied from 10 to 20 .

\subsection{Sampling and Measurement}

All fruits were harvested on November 12 and were divided into six size classes. These were $161-180 \mathrm{~g}, 181-210 \mathrm{~g}, 211-230 \mathrm{~g}, 231-250 \mathrm{~g}, 251-280 \mathrm{~g}$, and 281 - $320 \mathrm{~g}$. Ten fruits per size class were randomly sampled from each tree, and all 180 fruits from the three trees were used to measure individual fruit characteristics. The weights, lengths and diameters of the fruits were recorded first, and then skin color was measured as Hunter a value using a colorimeter (CM-2500d, Konica Minolta Sensing Inc., Japan). A fruit firmness tester (53,205, Turoni srl., Forlì, Italy) equipped with a 5-mm plunger was used to measure flesh firmness. Fruit juice was collected from sliced mesocarps using a hand presser, and the soluble solids were determined by a digital refractometer with an accuracy of \pm 0.2\% (PAL-1, Atago Co., Tokyo, Japan). Seeds were numbered from the cross section of the fruits. The dry matter ratios of the fruits were calculated from fresh weight of some flesh slices and dry weight of the slices dried at $80^{\circ} \mathrm{C}$ for 48 h.

\subsection{Nutrient Analysis}

The dried samples used to measure the dry matter ratio were ground to pass through a 20 -mesh. To determine total N, 0.2-g sub-samples were analyzed by a Kjeldahl instrument (Kjeltec 2300, Foss Tecator AB, Höganäs, Sweden) using the micro-Kjeldahl method [14]. P, K, Ca, and $\mathrm{Mg}$ were analyzed using an inductively coupled plasma emission spectrometer (ICPS-7510, Shimadzu Co., Tokyo, Japan) after digesting $0.5 \mathrm{~g}$ of the samples with $\mathrm{HClO}_{4}$ and $\mathrm{H}_{2} \mathrm{SO}_{4}$ in a heating block.

\subsection{Statistical Analysis}

Three single-tree replicates for each size class were arranged in a completely randomized design. Differences among the data were detected by Duncan's multiple-range test using the SAS System for Windows V8 (SAS Institute, Inc., Cary, NC, USA). Regression analysis was also performed in order to determine the relationships between fruit size and other fruit characteristics and mineral nutrient concentrations.

\section{Results and Discussion}

\subsection{Fruit Characteristic}

Table 1 shows the characteristic of the fruits from the different size classes after 
Table 1. Fruit characteristics as affected by different sizes of "Fuyu" persimmon fruits harvested on November 12.

\begin{tabular}{cccccccc}
\hline $\begin{array}{c}\text { Fruit size } \\
(\mathrm{g})\end{array}$ & $\begin{array}{c}\text { Avg. fresh } \\
\text { wt }(\mathrm{g})\end{array}$ & $\begin{array}{c}\text { Length/ } \\
\text { diameter }\end{array}$ & $\begin{array}{c}\text { Skin color } \\
(\text { Hunter } \mathrm{a})\end{array}$ & $\begin{array}{c}\text { Flesh } \\
\text { firmness } \\
(\mathrm{N})\end{array}$ & $\begin{array}{c}\text { Soluble } \\
\text { solids } \\
\left({ }^{\circ} \text { Brix }\right)\end{array}$ & $\begin{array}{c}\text { Seeds } \\
(\text { No./fruit })\end{array}$ & $\begin{array}{c}\text { Dry } \\
\text { matter } \\
(\%)\end{array}$ \\
\hline $161-180$ & $171 \mathrm{f}^{\beth}$ & $0.71 \mathrm{a}$ & $32.9 \mathrm{~cd}$ & $30.0 \mathrm{a}$ & $14.7 \mathrm{a}$ & $1.5 \mathrm{~b}$ & $16.7 \mathrm{a}$ \\
$181-210$ & $197 \mathrm{e}$ & $0.70 \mathrm{ab}$ & $32.3 \mathrm{~d}$ & $27.9 \mathrm{ab}$ & $14.9 \mathrm{a}$ & $2.9 \mathrm{ab}$ & $16.9 \mathrm{a}$ \\
$211-230$ & $220 \mathrm{~d}$ & $0.68 \mathrm{bc}$ & $33.5 \mathrm{~cd}$ & $27.5 \mathrm{ab}$ & $14.8 \mathrm{a}$ & $2.7 \mathrm{ab}$ & $16.7 \mathrm{a}$ \\
$231-250$ & $239 \mathrm{c}$ & $0.68 \mathrm{c}$ & $34.5 \mathrm{bc}$ & $26.7 \mathrm{bc}$ & $15.0 \mathrm{a}$ & $2.7 \mathrm{ab}$ & $17.1 \mathrm{a}$ \\
$251-280$ & $259 \mathrm{~b}$ & $0.67 \mathrm{c}$ & $35.9 \mathrm{ab}$ & $26.2 \mathrm{bc}$ & $15.0 \mathrm{a}$ & $3.1 \mathrm{a}$ & $17.0 \mathrm{a}$ \\
$281-320$ & $292 \mathrm{a}$ & $0.66 \mathrm{c}$ & $37.1 \mathrm{a}$ & $24.2 \mathrm{c}$ & $15.1 \mathrm{a}$ & $3.0 \mathrm{a}$ & $17.0 \mathrm{a}$ \\
\hline
\end{tabular}

${ }^{z}$ Mean values in each column with the same letter are not significantly different by Duncan's multiple range test at $P \leq 0.05$.

they had been harvested on November 12. The L/D ratio and flesh firmness significantly decreased as fruit size increased. The L/D ratio gradually changed from 0.71 for 161 - $180 \mathrm{~g}$ size class to 0.66 for 281 - $320 \mathrm{~g}$ size and flesh firmness fell from 30 to $24.2 \mathrm{~N}$, respectively. Large fruits had a redder skin color with more seeds than small ones. As fruit size increased from 161 - $180 \mathrm{~g}$ to $281-320$ $\mathrm{g}$, Hunter a value of the fruit skin increased from 32.9 to 37.1 and the number of seeds increased 2-fold more. Although soluble solids were higher in larger sized fruit, this difference was not statistically significant. Fruit size did not affect the dry matter ratio. Table 2 shows that there was a strong negative relationship between fruit size and the $L / D$ ratio $\left(R^{2}=0.741\right)$ and firmness $\left(R^{2}=0.604\right)$. Skin color and the number of seeds were positively related to fruit size, especially skin color $\left(\mathrm{R}^{2}=0.771\right)$. Although not significant, there was a weak positive relationship between fruit size and soluble solids.

Previous studies suggested that increasing fruit size by reducing the fruit load could advance fruit coloration and maturity [1] since carbohydrate availability increased [4] [5]. However, the fruit characteristics in this study might be affected by other factors as well as fruit load. Different light interceptions within a tree canopy could change physiological fruit drop, which would alter fruit load on the branches [15] [16]. The different light environments might also affect growth, coloration, and soluble sugar concentration in fruits [15] [17] [18]. It has previously been shown that the number of seeds per fruit could change fruit growth and coloration, since fruit seeds enhance sink activity for photosynthates [8] [16] [19].

Regardless of the various factors, large fruits in this study might mature faster than small ones, when their higher skin color and lower flesh firmness are considered. The lower $\mathrm{L} / \mathrm{D}$ ratios of large fruits indicated that the active growth of diameter occurs with increasing fruit weight. Higher skin color in large fruit indicated that the large fruits were produced from branches with better light interception or with low fruit load. Lower firmness in large fruits could be directly 
related to earlier maturation at harvest [3] [10] and higher cell volumes [20], compared with the small fruits. In addition, Johnson (1992) [2] observed that the increased proportion of intercellular spaces in large fruits was negatively related to flesh firmness. Insignificant change in soluble solids, despite a clear difference between fruit size and skin color, reflected that the soluble solids were more affected by other factors. The positive relationship between fruit size and the number of seeds (Table 2) confirmed that the number of seeds is positively correlated with fruit growth as previously reported [16].

\subsection{Mineral Nutrient}

Concentrations of $\mathrm{P}, \mathrm{K}$, and $\mathrm{Ca}$ significantly decreased as fruit size increased (Table 3). The concentrations did not apparently change when fruit size class increased from 161 - 180 to 211 - $230 \mathrm{~g}$. However, when fruit size increased from $211-230 \mathrm{~g}$ to $281-320 \mathrm{~g}, \mathrm{P}$ decreased from 0.093 to $0.078 \%$, $\mathrm{K}$ from 0.99 to $0.94 \%$, and $\mathrm{Ca}$ from 0.092 to $0.82 \%$. Therefore, there were highly negative relationships in the linear regression model between fruit size and fruit $\mathrm{P}\left(\mathrm{R}^{2}=\right.$ $\left.0.393^{* *}\right), \mathrm{K}\left(\mathrm{R}^{2}=0.446^{\star *}\right)$, and $\mathrm{Ca}\left(\mathrm{R}^{2}=0.417^{\star *}\right)$ concentrations (Table 4). On the other hand, increasing fruit size did not affect concentrations of $\mathrm{N}$ and $\mathrm{Mg}$ in the fruit (Table 3) and there is no significant relationship between fruit size and concentrations of $\mathrm{N}$ and $\mathrm{Mg}$.

In persimmon, contents of mineral nutrientsper fruit increase with fruit growth until harvest, but their concentrations gradually decrease as the fruit approaches the maturing stage because they are diluted by rapid fruit swelling [21] [22]. In contrast, there was an increase in $\mathrm{N}$ and $\mathrm{P}$ concentrations as apple fruit size increased [9] [23]. Wünsche and Ferguson (2005) [3] suggested that low concentrations of some mineral nutrients in large fruits under low fruit load are related to the increase in dry matter due to high fruit carbohydrate levels. In particular, rapidly growing fruits contain lower $\mathrm{Ca}$ concentration since the $\mathrm{Ca}$ accumulation cannot keep up with fruit expansion, whereas it is more likely to be accumulated in slowly growing fruits [3] [23]. Fallahi et al. (1984) [9] also reported that the flesh $\mathrm{Ca}$ concentrations decreased in large apple fruits produced

Table 2. Regression equations and coefficients of determination $\left(\mathrm{R}^{2}\right)$ between size $(\mathrm{X})$ and other characteristic factors $(\mathrm{Y})$ in fruits harvested on November $12(\mathrm{n}=18)$.

\begin{tabular}{ccc}
\hline Fruit characteristic & Regression equation & $\mathrm{R}^{2}$ \\
\hline Length/diameter (\%) & $\mathrm{Y}=-0.044 \mathrm{X}+78.6$ & $0.741^{\star *}$ \\
Skin color (Hunter a) & $\mathrm{Y}=0.041 \mathrm{X}+25.1$ & $0.771^{\star *}$ \\
Firmness (N) & $\mathrm{Y}=-0.043 \mathrm{X}+36.9$ & $0.604^{\star *}$ \\
Soluble solids ( ${ }^{\circ}$ Brix) & $\mathrm{Y}=0.003 \mathrm{X}+14.2$ & $0.184^{\mathrm{NS}}$ \\
Seeds (No./fruit) & $\mathrm{Y}=0.010 \mathrm{X}+0.3$ & $0.260^{*}$ \\
Dry matter (\%) & $\mathrm{Y}=3 \mathrm{E}-05 \mathrm{X}+0.2$ & $0.145^{\mathrm{NS}}$ \\
\hline
\end{tabular}

Ns, ${ }^{*},{ }^{* *}$ Non-significant or significant at $P \leq 0.05$ and $P \leq 0.01$, respectively. 
Table 3. Concentration of mineral nutrients in the fruit as affected by different sizes of "Fuyu" persimmon fruits harvested on November 12.

\begin{tabular}{cccccc}
\hline \multirow{2}{*}{$\begin{array}{c}\text { Fruit size } \\
(\mathrm{g})\end{array}$} & $\mathrm{N}$ & $\mathrm{P}$ & $\mathrm{K}$ & $\mathrm{Ca}$ & $\mathrm{Mg}$ \\
\cline { 2 - 6 } & $0.36 \mathrm{a}^{\mathrm{z}}$ & $0.092 \mathrm{a}$ & $1.03 \mathrm{a}$ & $0.091 \mathrm{ab}$ & $0.045 \mathrm{a}$ \\
\hline $161-180$ & $0.38 \mathrm{a}$ & $0.095 \mathrm{a}$ & $1.00 \mathrm{ab}$ & $0.093 \mathrm{a}$ & $0.043 \mathrm{a}$ \\
$181-210$ & $0.39 \mathrm{a}$ & $0.093 \mathrm{a}$ & $0.99 \mathrm{ab}$ & $0.092 \mathrm{a}$ & $0.044 \mathrm{a}$ \\
$211-230$ & $0.40 \mathrm{a}$ & $0.083 \mathrm{ab}$ & $0.95 \mathrm{ab}$ & $0.088 \mathrm{ab}$ & $0.044 \mathrm{a}$ \\
$231-250$ & $0.36 \mathrm{a}$ & $0.087 \mathrm{ab}$ & $0.95 \mathrm{ab}$ & $0.085 \mathrm{ab}$ & $0.043 \mathrm{a}$ \\
$251-280$ & $0.37 \mathrm{a}$ & $0.078 \mathrm{~b}$ & $0.94 \mathrm{~b}$ & $0.082 \mathrm{~b}$ & $0.043 \mathrm{a}$ \\
\hline $281-320$ & &
\end{tabular}

${ }^{2}$ Mean values in each column with the same letter are not significantly different by Duncan's multiple range test at $P \leq 0.05$.

Table 4. Regression equations and coefficients of determination $\left(\mathrm{R}^{2}\right)$ between size (X) and mineral nutrient concentrations $(\mathrm{Y})$ in fruits harvested on November $12(\mathrm{n}=18)$.

\begin{tabular}{ccc}
\hline Mineral nutrients (\% DW) & Regression equation & $\mathrm{R}^{2}$ \\
\hline Nitrogen & $\mathrm{Y}=2 \mathrm{E}-07 \mathrm{X}+0.374$ & $\mathrm{R}^{2}=9 \mathrm{E}-08^{\mathrm{NS}}$ \\
Phosphorous & $\mathrm{Y}=-0.0001 \mathrm{X}+0.117$ & $\mathrm{R}^{2}=0.393^{* *}$ \\
Potassium & $\mathrm{Y}=-0.0008 \mathrm{X}+1.158$ & $\mathrm{R}^{2}=0.446^{* *}$ \\
Calcium & $\mathrm{Y}=-9 \mathrm{E}-05 \mathrm{X}+0.109$ & $\mathrm{R}^{2}=0.417^{* *}$ \\
Magnesium & $\mathrm{Y}=-8 \mathrm{E}-06 \mathrm{X}+0.046$ & $\mathrm{R}^{2}=0.022^{\mathrm{NS}}$ \\
\hline
\end{tabular}

Ns, ${ }^{* *}$ Non-significant or significant at $P \leq 0.01$, respectively.

from low fruit load trees. Low Ca concentration in large fruits could reduce fruit storability [10]. Therefore, low flesh firmness in the large fruits (Table 1) could be related to their low Ca concentration. Non-significant changes in $\mathrm{N}$ and $\mathrm{Mg}$ concentrations of fruit (Table 3) indicated that the larger the fruits, the more they absorbed $\mathrm{N}$ and $\mathrm{Mg}$, compared to the other nutrients. However, some previous reports have indicated that fruit $\mathrm{N}$ and $\mathrm{Mg}$ concentrations were not affected by fruit size [11] [23].

\section{Conclusion}

Taken together, the consumer market for small "Fuyu" fruits could be limited due to their lower coloration and higher firmness when the fruits are difficult to mature sufficiently under the risk of early frost damage as in the major persimmon growing areas of Korea. However, higher firmness of the small could improve long-term storage, which is important for the export market. Large fruits are more suitable for short-term consumption because they have better skin coloration with soft flesh, but careful attention should be paid to prevent large fruits from rapidly softening during the postharvest period. The result from this study also indicated that flesh firmness of fruit could be partially related to 
changes in the concentrations of some mineral nutrients in the fruit, especially Ca.

\section{Acknowledgements}

We gratefully acknowledge the financial support of the "Cooperative Research Program for Agricultural Science \& Technology Development" (Project No. PJ013553022018) from the Rural Development Administration of the Republic of Korea.

\section{Conflicts of Interest}

The authors declare that there is no conflict of interest.

\section{References}

[1] Choi, S.T., Park, D.S., Kang, S.M. and Cho, Y.C. (2010) Effect of Fruit-Load on the Growth, Absorption, and Partitioning of Inorganic Nutrients in Young "Fuyu" Persimmon Trees. Scientia Horticulturae, 126, 408-412. https://doi.org/10.1016/j.scienta.2010.07.035

[2] Ohnson, D.S. (1992) The Effect of Flower and Fruitlet Thinning on the Firmness of “Cox's Orange Pippin” Apples at Harvest and after Storage. Journal of Horticultural Science, 67, 95-101. https://doi.org/10.1080/00221589.1992.11516225

[3] Wünsche, J.N. and Ferguson, I.B. (2005) Crop Load Interactions in Apple. Horticultural Reviews, 31, 231-290. https://doi.org/10.1002/9780470650882.ch5

[4] Embree, C.G., Myra, M.T.D., Nichols, D.S. and Wright, A.H. (2007) Effect of Blossom Density and Crop Load on Growth, Fruit Quality, and Return Bloom in "Honeycrisp" Apple. HortScience, 42, 1622-1625. https://doi.org/10.21273/HORTSCI.42.7.1622

[5] Walter, T.E. (1967) Factors Affecting Colour in Apples: A Review of World Literature. Annual Report of East Malling Research Station 1966, 70-82.

[6] Kitajima, A., Matsumoto, T., Ishida, M. and Sobajima, Y. (1990) Relationship between Dry Matter Production of Bearing Shoots and Physiological Fruit Drop of Japanese Persimmon, by Shading Treatments. Journal of the Japanese Society for Horticultural Science, 59, 75-81. https://doi.org/10.2503/jjshs.59.75

[7] Choi, S.T., Park, D.S., Cho, Y.C. and Kang, S.M. (2009) Effect of Different Degrees of Local Defoliation in "Fuyu" Persimmon on Fruit and Tree Development in the Current and Following Years. Horticulture Environment and Biotechnology, 50, 74-78.

[8] Hasegawa, K. and Nakajima, Y. (1990) Effects of Seediness on Fruit Quality of Japanese Persimmon cv. Maekawa-Jiro. Journal of the Japanese Society for Horticultural Science, 59, 255-262. https://doi.org/10.2503/jjshs.59.255

[9] Fallahi, E., Westwood, M.N., Richardson, D.G. and Chaplin, M.H. (1984) Effects of Rootstocks and K and N Fertilizers on Seasonal Apple Fruit Mineral Composition in a High Density Orchard. Journal of Plant Nutrition, 7, 1179-1201. https://doi.org/10.1080/01904168409363274

[10] Greene, D.W., Autio, W.R., Erf, J.A. and Mao, Z.Y. (1992) Mode of Action of Benzyladenine When Used as a Chemical Thinner on Apples. Journal of the American Society for Horticultural Science, 117, 775-779. 
https://doi.org/10.21273/JASHS.117.5.775

[11] Volz, R.K., Ferguson, I.B., Bowen, J.H. and Watkins, C.B. (1993) Crop Load Effects on Fruit Mineral Nutrition, Maturity, Fruiting and Tree Growth of "Cox's Orange Pippin” Apple. Journal of Horticultural Science, 68, 127-137. https://doi.org/10.1080/00221589.1993.11516336

[12] Greene, D.W. and Autio, W.R. (1989) Evaluation of Benzyladenine as a Chemical Thinner on "McIntosh" Apples. Journal of the American Society for Horticultural Science, 114, 68-73.

[13] RDA (Rural Development Administration) (2013) Standard Agricultural Manual: Persimmon Growing. RDA, Suwon.

[14] Nelson, D.W. and Sommers, L.E. (1973) Determination of Total Nitrogen in Plant Material. Agronomy Journal, 65, 109-112. https://doi.org/10.2134/agronj1973.00021962006500010033x

[15] Choi, S.T., Kang, S.M. and Kim, T.C. (2006) Fruit Characteristics and Storability of "Fuyu" Persimmon as Affected by Location of the Orchards and Position within the Tree Canopy. Korean Journal of Horticultural Science and Technology, 24, 359-363.

[16] Kitajima, A., Ohshita, Y., Nakano, M. and Ishida, M. (1993) Comparisons of Fruit Set and Quality between Seeded and Parthenocarpic Kaki Fruits cv. Fuyu in Relation to the Location of the Fruiting Shoot. Journal of the Japanese Society for Horticultural Science, 62, 505-512. https://doi.org/10.2503/jjshs.62.505

[17] Erez, A. and Flore, J.A. (1986) The Quantitative Effect of Solar Radiation on Anthocyanin Production in "Redhaven" Peach Skin Color. HortScience, 21, 1424-1429.

[18] Seeley, E.J., Micke, W.C. and Kammereck, R. (1980) “Delicious" Apple Fruit Size and Quality as Influenced by Radiant Flux Density in the Immediate Growing Environment. Journal of the American Society for Horticultural Science, 105, 645-657.

[19] Choi, S.T., Park, D.S., Kim, J.B., Kang, S.M. and Kim, T.C. (2006) Production of Seedless "Maekawa-Jiro" Persimmon by Blocking the Pollinators. Korean Journal of Horticultural Science and Technology, 24, 370-375.

[20] De Salvador, F.R., Fisichella, M. and Fontanari, M. (2006) Correlations between Fruit Size and Fruit Quality in Apple Trees with High and Standard Crop Load Levels. Journal of Fruit and Ornamental Plant Research, 14, 113-122.

[21] Fukui, H., Suzuki, Y., Horibe, T. and Goto, M. (1997) Potassium, Calcium, and Magnesium Uptake of Japanese Persimmon Trees in Root Restricted Culture. Acta Horticulturae, 436, 285-294. https://doi.org/10.17660/ActaHortic.1997.436.31

[22] Fukui, H., Suzuki, Y., Ogawa, E., Hirata, K., Matsubara, Y. and Nakamura, M. (1999) Nitrogen Uptake by Three- to Four-Year-Old Potted Trees of Japanese Persimmon "Nishimurawase". Journal of the Japanese Society for Horticultural Science, 68, 578-584.

[23] Marmo, C.A., Bramlage, W.J. and Weis, S.A. (1985) Effects of Fruit Maturity, Size, and Mineral Concentrations on Predicting the Storage Life of "McIntosh" Apples. Journal of the American Society for Horticultural Science, 110, 499-502. 